\title{
USING SENSES AND SENSORS IN THE ENVIRONMENT TO DEVELOP ABSTRACT THINKING - A THEORETICAL AND INSTRUMENTAL FRAMEWORK
}

\author{
Maria João Silva \\ Polytechnic Institute of Porto, Porto, Portugal \\ E-mail: mjosilva@ese.ipp.pt
}

\author{
Joaquim Bernardino Lopes \\ University of Trás-os-Montes e Alto Douro, Vila Real, Portugal \\ CIDTFF - Research Centre "Didactics and Technology in Education of Trainers" \\ E-mail: blopes@utad.pt \\ António Alberto Silva \\ Polytechnic Institute of Porto, Porto, Portugal \\ E-mail: aasilva@ese.ipp.pt
}

\begin{abstract}
The authors of this paper present a framework developed in a project that explores the use of senses and sensors in environmental education, to develop children's abstract thinking. The research started with a briefformulation of a framework that was used to guide the cross-analysis of six case studies, in order to explore its usefulness. This analysis showed that it was possible to teachers to support the development of children's abstract thinking by facilitating the use of senses and sensors in inquiry activities; and by scaffolding complex tasks, using concreteness fading, and bridging representations, with different levels of abstraction. The analysis also showed that the assessment of the development of abstract thinking can be based on the analysis of children's epistemic practices, like observing, describing, interpreting, and creating multiple representations. Furthermore, the cross-analysis showed that sensorial information was used as a concrete basis to abstraction. After that, an improved framework is presented, showing how senses and sensors may be used in authentic activities to develop abstract thinking: (a) making it possible to observe the unobservable (for human senses), (b) scaffolding the understanding of patterns resulting from the influence of independent in dependent variables, (c) facilitating epistemic practices.
\end{abstract}

Key words: abstract thinking, environmental education, senses, sensors.

\section{Introduction}

The importance of investigative, authentic, situated and embodied activities to the development of scientific literacy has been emphasized in science education approaches, namely in the context of elementary schools (Figueiredo \& Afonso, 2006; Lombardi, 2007; Osborne \& Dillon, 2008; Quintana et al., 2004). In this paper, the authors present: (a) an analysis of the potential of the joint use of human senses and sensors to scaffold the development of children's abstract thinking that is needed to the success of the aforementioned authentic activities; (b) a framework to support the use of sensors and senses to develop children's abstract thinking in environmental education. These analysis and framework were developed in the context of a research project, named SOS Abstract (Using Sensors and Senses in the Environment to Develop Abstract Thinking). 
Maria João SILVA, Joaquim BERNARDINO LOPES, António Alberto SILVA. Using Senses and Sensors in the Environment to Develop Abstract Thinking - a Theoretical and Instrumental Framework

$\begin{array}{r}\text { PROBLEMS } \\ \text { OF EDUCATION } \\ \text { IN THE 21 } 1^{\text {st }} \text { CENTURY } \\ \text { Volume 53, 2013 } \\ \hline 100\end{array}$

\section{Research Problem}

The problem worked in this research is the need for improving children's thinking processes in elementary schools (OECD, 2010), namely in science education (Brites, Calado, Estêvão, Carvalho, \& Conceição, 2011). This research problem is tackled by focusing on the potential of the joint use of senses and sensors to improve the development of abstract thinking in the context of hands-on authentic inquiry activities.

The central objective of this research is to develop a framework to support: the design and the analysis of activities using human senses and sensors, focusing on how they can improve the development of children's abstract thinking.

\section{Related Work}

In the context of their critical reflections on science education in Europe, Osborne and Dillon (2008) stress that the emphasis in science education before 14 should be on engaging students with science and scientific phenomena, namely through extended investigative work and 'hands-on' experimentation. At the same time, authentic learning has been pointed as a $21 \mathrm{st}$ century approach (Lombardi, 2007). Authentic learning integrates real-world and ill-defined learning problems, collaborative problem solving, ICT tools, situated learning, and opportunities for students to link previous knowledge to the knowledge being acquired (Brown, Collins, \& Duguid, 1989; Figueiredo, 2005; Henning, 2004; Hilton, 2010; Lombardi, 2007). To promote children's success in authentic activities, it is necessary to scaffold the development of children's abstract thought (Lombardi, 2007; Quintana et al., 2004). Scaffolding is the process by which a learner is supported to succeed in problems that s/he couldn't handle alone (Quintana et al., 2004). Three key characteristics of scaffolding should be considered (Van de Pol, Volman, \& Beishuizen, 2010): contingency (scaffolded strategies should be based on student responses), concreteness fading over time, and transfer of responsibility to students. Concreteness fading is the successively decreasing of the concreteness of the representations, to attain an abstract representation that is still connected to the situation represented (Goldstone, \& Son, 2005).

Since senses are the primary human-environment interface, they are part of people's everyday lives and experiences (Mason, \& Davies, 2009) and necessary elements in moving from concrete to abstract thinking (Minogue, \& Jones, 2006). Therefore, there is a need for addressing the role of the body in children's constructions of meanings (Woodyer, 2008).

Sensors are typically used as an extension of human senses (Magnani, 2004). They can play an important role as manipulable mediators in learning by internalization (Lopes, Cravino, Silva, \& Viegas, 2012). Electronic sensors are becoming everyday devices, allowing the integrated use of senses and sensors in mobile and ubiquitous learning activities (Silva, Lopes, Silva, \& Marcelino, 2010). For instance, mobile phones integrate a set of electronic sensors (e.g., photo, video and audio recorders, GPS, accelerometer); and they are portable, affordable, wireless, connectible and can be used anytime, anywhere (Knight, 2005; Shuler, 2009; Silva et al., 2010).

There is recent research literature about how epistemic mediators can scaffold scientific inquiry., e.g.: software tools as epistemic mediators (Lopes, et al., 2012; Magnani, 2004; Quintana et al., 2004; Reiser, 2004; Yelland, \& Masters, 2007); the role of sensors in the development of children's abstract thinking in science (Fenton, 2008; Heggen, Omokaro, \& Payton, 2012; Le Boniec, Gras-Velázquez \& Joyce, 2012; Rogers, Connelly, Hazlewood, \& Tedesco, 2010). In this context, it is important to outline a noteworthy set of issues:

- Electronic sensors can also add to children's abilities, such as to use scientific methods (Le Boniec, et al., 2012) and to evaluate critically the use of data (Fenton, 2008; Le Boniec, et al., 2012), in this way developing children's abstract thinking;

- Supported by the embodied, hands-on and situated use of senses and sensors, children's action in the environment scaffolds the learning of abstract topics, in the course 
of (Reiser, 2004): the manipulation of concrete things; the control of sense data (for instance, how we can change the use of our senses and of sensors as senses' extensions); the search for consistent information; and the building of multiple representations (as the recordings of sensory information or the graphics produced with information acquired by sensors);

- Electronic sensors, together with data-loggers, can be considered cognitive tools that change what can be accomplished by a child, or a group, facilitating the complex task of monitoring environmental variables (Reiser, 2004). By providing meaningful representations of environmental states, these tools can support the development of more in-depth models of natural phenomena and improve the level of scientific reasoning children can perform (Reiser, 2004);

- The use of multiple representations and an improved mapping between tool's representations, what they represent and children's point of view can reduce the complexity and in this way scaffold the task (Norman, 1991; Quintana et al., 2004; Reiser, 2004; Rogers, et al., 2010);

- Scaffolding the development of children's abstract thinking through the use of tools, such as electronic sensors, can be improved applying strategies that (Quintana et al., 2004): provide visual organizers; use descriptions of complex concepts and models that build on learners' models; provide representations to reveal underlying properties of data; enable learners to navigate among activities, tools, and representations; facilitate articulation during sense making; make scientific strategies explicit; highlight epistemic practices.

The assessment of the development of children's abstract thinking, in the context of authentic activities, should use authentic assessment techniques (Figueiredo, 2005) that engage children in tasks of authentic (real word) problem solving developed in meaningful environmental education contexts. Examples of authentic assessment techniques are projects, learning portfolios and presentations (Figueiredo, 2005). Accordingly, the analysis of children's epistemic practices, such as observing/sensing, describing, discussing, interpreting, formulating hypothesis, selecting variables, planning procedures, controlling variables, creating multiple representations, and modelling, can contribute in a significant way to assess the development of children's abstract thinking in authentic inquiry (Chinn, \& Malhotra 2002; Lopes, et al., 2012).

\section{A Framework about Senses and Sensors to Develop Abstract Thinking - Brief Formulation}

The central research question of the study presented in this paper is: Which theoretical and instrumental issues should be addressed in a framework that aims: (a) to support the analysis of how authentic environmental education activities, which use human senses and sensors, can contribute to the development of children's abstract thinking; (b) to give grounded insights to teachers, helping them to use senses and sensors in authentic activities to improve abstract thinking.

Such framework intends to fill a gap situated in the frontier between the domains of ICT in Education and Science Education, addressing the role of the joint use of senses and sensors in scaffolding the development of children's abstract thinking. This framework aims at synthesizing knowledge from the research literature and field of practice.

The framework, based on the review of the literature and on previous work (Silva et al., 2010), has four dimensions (Table 1). The first dimension is related to how the sensors can be used by children and to what is relevant in such use. It is focused on: facilitating the effective use of different sensors; and on searching and recording relevant information in authentic and complex tasks. The second dimension is related to the use of the senses in a conscious and de- 
Maria João SILVA, Joaquim BERNARDINO LOPES, António Alberto SILVA. Using Senses and Sensors in the Environment to Develop Abstract Thinking - a Theoretical and Instrumental Framework

OF EDUCATION

IN THE $21^{\text {st }}$ CENTURY Volume 53, 2013

102

liberate way. The third dimension is about teacher mediation of student learning. It is focused on scaffolding complex tasks, using concreteness fading, and bridging representations with different levels of abstraction. The last dimension of the framework makes explicit some of the most important practices of abstract thinking. It allows, both, to assess the development of abstract thinking and to draw the attention to what kind of practices are relevant, in educational settings, to develop the abstract thinking using senses and sensors. In this framework the four dimensions should be faced in articulated way.

Table 1. Framework (brief formulation) to inform the design and the assessment of the use of senses and sensors to develop abstract thinking.

\begin{tabular}{|c|c|}
\hline Dimensions & Sub dimensions \\
\hline 1. Children's use of sensors & $\begin{array}{l}\text { 1.1 Improved students' awareness for the diverse sensors and their func- } \\
\text { tions; } \\
\text { 1.2 Effective uses of sensors and for what; } \\
\text { 1.3 Students awareness about environmental information obtained by sen- } \\
\text { sors (Le Boniec, Gras-Velázquez \& Joyce 2012); } \\
\text { 1.4 Recordings of environmental information; } \\
\text { 1.5 Search for information obtained only by sensors; }\end{array}$ \\
\hline $\begin{array}{l}\text { 2. Children's use of senses, sensorial } \\
\text { information }\end{array}$ & $\begin{array}{l}\text { 2.1 Control of sense data (Reiser, 2004); } \\
\text { 2.2 Familiarization with natural phenomena, enhancing concreteness } \\
\text { (Reiser, 2004); } \\
\text { 2.3 Search for consistent information (Reiser, 2004); }\end{array}$ \\
\hline $\begin{array}{l}\text { 3. Scaffolding in Teachers-Children- } \\
\text { Sensors Interactions }\end{array}$ & $\begin{array}{l}\text { 3.1 Discussing what to do, what happened, why happened, what will hap- } \\
\text { pen... } \\
\text { 3.2 Making scientific strategies visible (Quintana et al., 2004):: } \\
\text { 3.2.1 Experiment plans; } \\
\text { 3.2.2. Observation tables and charts, requiring records of senses and sen- } \\
\text { sors in multiple formats and separating observations from interpretation and } \\
\text { estimative; } \\
\text { 3.3 Mapping/Bridging representations, including concreteness fading } \\
\text { (Goldstone, \& Son, 2005) } \\
\text { 3.4 Using descriptions of complex concepts/phenomena that build on } \\
\text { authentic and sensory experiences Quintana et al., 2004) }\end{array}$ \\
\hline $\begin{array}{l}\text { 4. Epistemic practices (Saraiva, Lopes, } \\
\text { Cravino \& Santos, 2012) }\end{array}$ & $\begin{array}{l}\text { 4.1 Observing/sensing } \\
\text { 4.2 Describing; } \\
\text { 4.3 Interpreting; } \\
\text { 4.4 Controlling variables; } \\
\text { 4.5 Creating multiple representations; } \\
\text { 4.6 Modelling. }\end{array}$ \\
\hline
\end{tabular}

\section{Methodology of Research}

In order to explore its usefulness, the framework presented above was used to guide the cross-analysis (Yin, 2003) of six (6) exploratory case studies (see Tables 1 and 2) that were developed, between 2010 and 2012, in the context of a Master Course (Experimental Science Teaching in Elementary Education). Those cases used senses and sensors in science hands-on authentic activities to develop science inquiry competences and the understanding of complex concepts (see Table 2). The cross-analysis was not meant to categorize all the results of the case studies. It aimed to be the basis of the framework, as in grounded theory (Cohen, Manion, \& Morrison, 2007), and to illustrate its usability. 
Table 2. Characterization of the six case studies.

\begin{tabular}{|c|c|c|c|c|c|}
\hline Case Study & Theme & Participants & $\begin{array}{l}\text { Studied } \\
\text { Concepts }\end{array}$ & Senses & $\begin{array}{l}\text { Sensors (elec- } \\
\text { tronic and non } \\
\text { electronic) }\end{array}$ \\
\hline $\begin{array}{l}\text { CS1 } \\
\text { (Teixeira, 2012) }\end{array}$ & $\begin{array}{l}\text { Complexity of } \\
\text { the life concept }\end{array}$ & $\begin{array}{l}\text { Teacher-researcher; } \\
2^{\text {nd }} \text { year of scholarity } \\
\text { class } \\
\text { (15 children) }\end{array}$ & $\begin{array}{l}\text { Biodiversity; } \\
\text { Living Being; }\end{array}$ & Vision & $\begin{array}{l}\text { Binocular loupe; } \\
\text { Digital microscope; } \\
\text { Optical microscope }\end{array}$ \\
\hline $\begin{array}{l}\text { CS2 } \\
\text { (Gonçalves, } \\
\text { 2012) }\end{array}$ & $\begin{array}{l}\text { Biodiversity } \\
\text { and Tempera- } \\
\text { ture in Tide } \\
\text { Pools }\end{array}$ & $\begin{array}{l}\text { Teacher-researcher; } \\
4^{\text {th }} \text { year of scholarity } \\
\text { class } \\
\text { ( } 26 \text { children) }\end{array}$ & $\begin{array}{l}\text { Biodiversity; } \\
\text { Temperature; }\end{array}$ & $\begin{array}{l}\text { Vision; Hear- } \\
\text { ing; Smell; } \\
\text { Skin senses } \\
\text { (touch and } \\
\text { sense of } \\
\text { temperature) }\end{array}$ & $\begin{array}{l}\text { Digital camera; } \\
\text { Mobile phones; } \\
\text { Temperature sen- } \\
\text { sor; }\end{array}$ \\
\hline $\begin{array}{l}\text { CS3 } \\
\text { (Nogueira, } \\
2012 \text { ) }\end{array}$ & $\begin{array}{l}\text { Somatic } \\
\text { Senses, } \\
\text { Temperature } \\
\text { and Heat }\end{array}$ & $\begin{array}{l}\text { Teacher-researcher; } \\
6^{\text {th }} \text { year of scholarity } \\
\text { class } \\
\text { ( } 21 \text { children) }\end{array}$ & Temperature; & $\begin{array}{l}\text { Vision; } \\
\text { Touch and } \\
\text { sense of } \\
\text { temperature }\end{array}$ & $\begin{array}{l}\text { Thermometer; Tem- } \\
\text { perature sensor; }\end{array}$ \\
\hline $\begin{array}{l}\text { CS4 } \\
\text { (Nunes, 2012) }\end{array}$ & $\begin{array}{l}\text { Environmental } \\
\text { sounds and } \\
\text { emotions }\end{array}$ & $\begin{array}{l}\text { Teacher-researcher; } \\
2^{\text {nd }} \text { year of scholarity } \\
\text { class } \\
\text { ( } 25 \text { children) }\end{array}$ & $\begin{array}{l}\text { Sound level; } \\
\text { Cardiac } \\
\text { rhythm }\end{array}$ & $\begin{array}{l}\text { Vision; Audi- } \\
\text { tion; Touch; }\end{array}$ & $\begin{array}{l}\text { Sound level sensor; } \\
\text { Cardiac rhythm } \\
\text { sensor }\end{array}$ \\
\hline $\begin{array}{l}\text { CS5 } \\
\text { (Leão, 2011) }\end{array}$ & $\begin{array}{l}\text { Photosynthe- } \\
\text { sis and Carbon } \\
\text { Cycle }\end{array}$ & $\begin{array}{l}\text { Teacher-researcher; } \\
\text { Science Club (15 } \\
\text { children in the } 6^{\text {th }} \text { year } \\
\text { of scholarity) }\end{array}$ & Carbon Cycle; & $\begin{array}{l}\text { Vision; } \\
\text { Skin senses; }\end{array}$ & $\begin{array}{l}\text { Carbon dioxide } \\
\text { sensor }\end{array}$ \\
\hline $\begin{array}{l}\text { CS6 (Moreira, } \\
\text { 2011) }\end{array}$ & $\begin{array}{l}\text { Microbiology } \\
\text { and Food } \\
\text { Conservation }\end{array}$ & $\begin{array}{l}\text { Teacher-researcher; } \\
6^{\text {th }} \text { year of scholarity } \\
\text { class } \\
\text { ( } 22 \text { children) }\end{array}$ & $\begin{array}{l}\text { Microbes and } \\
\text { the conserva- } \\
\text { tion of food }\end{array}$ & Vision; smell; & $\begin{array}{l}\text { Optical microscope; } \\
\text { Mobile phones }\end{array}$ \\
\hline
\end{tabular}

\section{Participants}

The 6 exploratory case studies were implemented in 6 Portuguese elementary schools (one case in each school). A total of 6 teachers and 124 children participated in the case studies (see Table 1). In each case study, the learning activities were developed with a group of children and the mediation of a teacher, which was also the researcher responsible for that case study (see Table 1).

\section{Data collection}

The learning activities' data of each case study were collected by each teacher-researcher, using participant observation. Researcher's annotations, photos, audio recordings as well as the drawings, tables, graphs and texts produced by children and sensors were the ways used to record observation data to be analyzed by each researcher. In the case studies, word tables (Yin, 2003) and multimodal narratives (Lopes et al., 2010) were used to organize and present data.

\section{Data analysis}

The cross-analysis of the 6 case studies was performed using the following guiding questions (see Table 1):

(a) How do students use senses, sensors and how do they articulate them?

(b) Along the joint use of human senses and electronic sensors, which aspects of scaffolding should be considered in order to develop children's abstract thinking?

(c) Which epistemic practices do students develop when using the sensors together with senses? 
Maria João SILVA, Joaquim BERNARDINO LOPES, António Alberto SILVA. Using Senses and Sensors in the Environment to Develop Abstract Thinking - a Theoretical and Instrumental Framework

PROBLEMS

OF EDUCATION

IN THE $21^{\text {st }}$ CENTURY

Volume 53, 2013

104

\section{Results of the Research}

The six case studies (Table 2) were analyzed, using the framework in its brief formulation (Table 1) and the guiding questions presented in the previous section. Some of the most meaningful illustrations of each dimension in the set of case studies are presented in this section.

\section{Children's Use of Senses, Sensors and How they Articulate Them}

In the case studies, children used the sensors in a sensory active way. The children used their senses to:

(a) Search for the more adequate conditions, such as magnification, location, point of view, and position, to use the sensor (see table 3 ).

(b) Compare their sensory assessments with the data acquired by the sensors (see table 4).

Table 3. Examples of the searching for the more adequate conditions to use a sensor.

\begin{tabular}{ll}
\hline Case Study & Examples of the searching for the more adequate conditions to use a sensor \\
\hline CS1 & After the sensory observation of a sample of pond water, children were asked about the pres- \\
& ence of microorganisms in that water. They suggested the use of the digital microscope and \\
they used it, as well as the binocular loupe and the optical microscope, to find out the answer \\
to the problem question. Children compared what they were able to see with and without the \\
loupe and the microscopes, making observations with different magnifications (see the image \\
below that shows the drawings made by a child, representing what s/he observed).
\end{tabular}

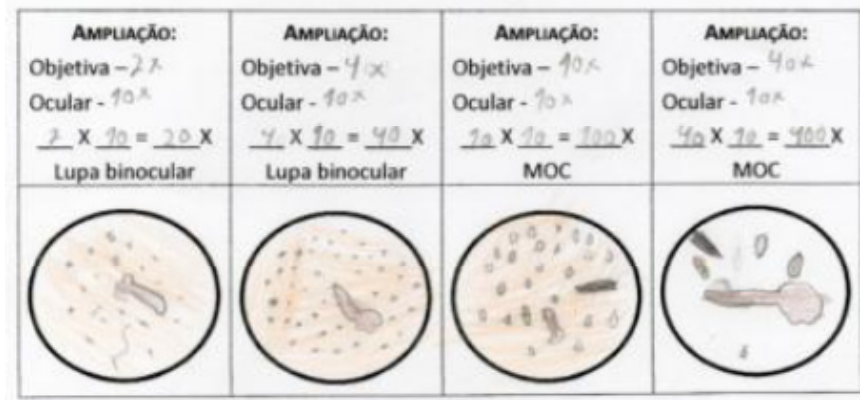

Translation:

Ampliação - Magnification;

Objetiva - Objecctive lens:

Ocular - Ocular lens;

Lupa binocular - Binocular loup;

MOC - Optical Microscope

$\begin{array}{ll}\text { CS2 } & \text { Due to unexpected external interventions, the classroom water temperature monitoring experi- } \\ \text { ment had to be repeated, since the position of the temperature sensor was changed. Fol- } \\ \text { lowing their planning decisions, children used their senses to monitor the controlled variable } \\ \text { (position of the sensor), detected the change of the sensor position, and replaced and fixed } \\ \text { the temperature sensor at the planned position. }\end{array}$


Maria João SILVA, Joaquim BERNARDINO LOPES, António Alberto SILVA. Using Senses and Sensors in the Environment to Develop Abstract Thinking - a Theoretical and Instrumental Framework

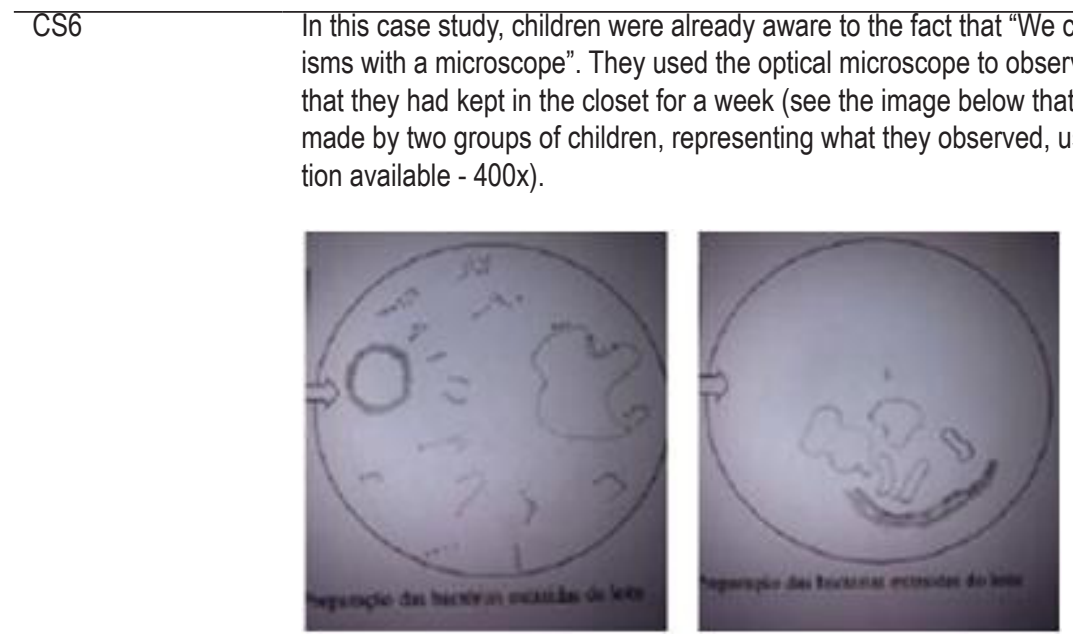

Translation:

Preparação das bactérias extraídas do leite - Microscopic preparation of milk bactéria;

Table 4. Examples of the of comparisons between sensory assessments and the sensors' data.

\begin{tabular}{|c|c|c|c|c|c|}
\hline Case Study & \multicolumn{5}{|c|}{ Examples of comparisons between sensory assessments and the sensors' data } \\
\hline CS2 & \multicolumn{5}{|c|}{$\begin{array}{l}\text { The data collected in the classroom water temperature monitoring experiment were related } \\
\text { and applied by children in the interpretation of their everyday sensory experiments, namely in } \\
\text { what concerns their perceptions of air and water temperatures. }\end{array}$} \\
\hline \multirow[t]{9}{*}{ CS3 } & \multicolumn{5}{|c|}{$\begin{array}{l}\text { Children, working in groups, were invited to make predictions (every } 5 \text { minutes in a period of } \\
20 \text { minutes) of the temperature of the water in a container. The initial water temperature was } \\
40^{\circ} \mathrm{C} \text {. After each prediction, children measure the temperature with a sensor. They improvec } \\
\text { their predictions, guided by the temperature data measured by the sensor (see the table } \\
\text { below). }\end{array}$} \\
\hline & \multicolumn{5}{|c|}{ Temperature of the water in the container } \\
\hline & \multirow{2}{*}{ Time/minutes } & \multicolumn{3}{|c|}{ Predicted temperature $\left({ }^{\circ} \mathrm{C}\right)$} & \multirow{2}{*}{$\begin{array}{c}\text { Measured tem- } \\
\text { perature }\left({ }^{\circ} \mathrm{C}\right)\end{array}$} \\
\hline & & Group A & Group B & Group C & \\
\hline & 0 minutes & $60^{\circ} \mathrm{C}$ & $50^{\circ} \mathrm{C}$ & $40^{\circ} \mathrm{C}$ & $38,5^{\circ} \mathrm{C}$ \\
\hline & 5 minutes & $30^{\circ} \mathrm{C}$ & $30^{\circ} \mathrm{C}$ & $35^{\circ} \mathrm{C}$ & $36^{\circ} \mathrm{C}$ \\
\hline & 10 minutes & $25,5^{\circ} \mathrm{C}$ & $30^{\circ} \mathrm{C}$ & $26^{\circ} \mathrm{C}$ & $34^{\circ} \mathrm{C}$ \\
\hline & 15 minutes & $31,5^{\circ} \mathrm{C}$ & $32^{\circ} \mathrm{C}$ & $29^{\circ} \mathrm{C}$ & $32^{\circ} \mathrm{C}$ \\
\hline & 20 minutes & $30^{\circ} \mathrm{C}$ & $30^{\circ} \mathrm{C}$ & $30^{\circ} \mathrm{C}$ & $31^{\circ} \mathrm{C}$ \\
\hline
\end{tabular}

Microscopes were used to observe microorganisms after the sensory observation of pond water (CS1) and of a sample of milk that was kept inside a closet for a week (CS6). This way, children were able to sense and observe the unobservable (see Table 3 ).

In the use of senses and sensors, children could produce and observe recordings of multisensory observations and multiple representations of data acquired by sensors (such as images, 
Maria João SILVA, Joaquim BERNARDINO LOPES, António Alberto SILVA. Using Senses and Sensors in the Environment to Develop Abstract Thinking - a Theoretical and Instrumental Framework

IN THE $21^{\text {st }}$ CENTURY Volume 53, 2013

tables and graphs). Mobile phones and digital cameras (CS2; CS6) were used by children to photograph a tide pools ecosystem and to photograph everyday situations at their homes related to the topic Microbes and Conservation of Food (see Figure 1).

a)

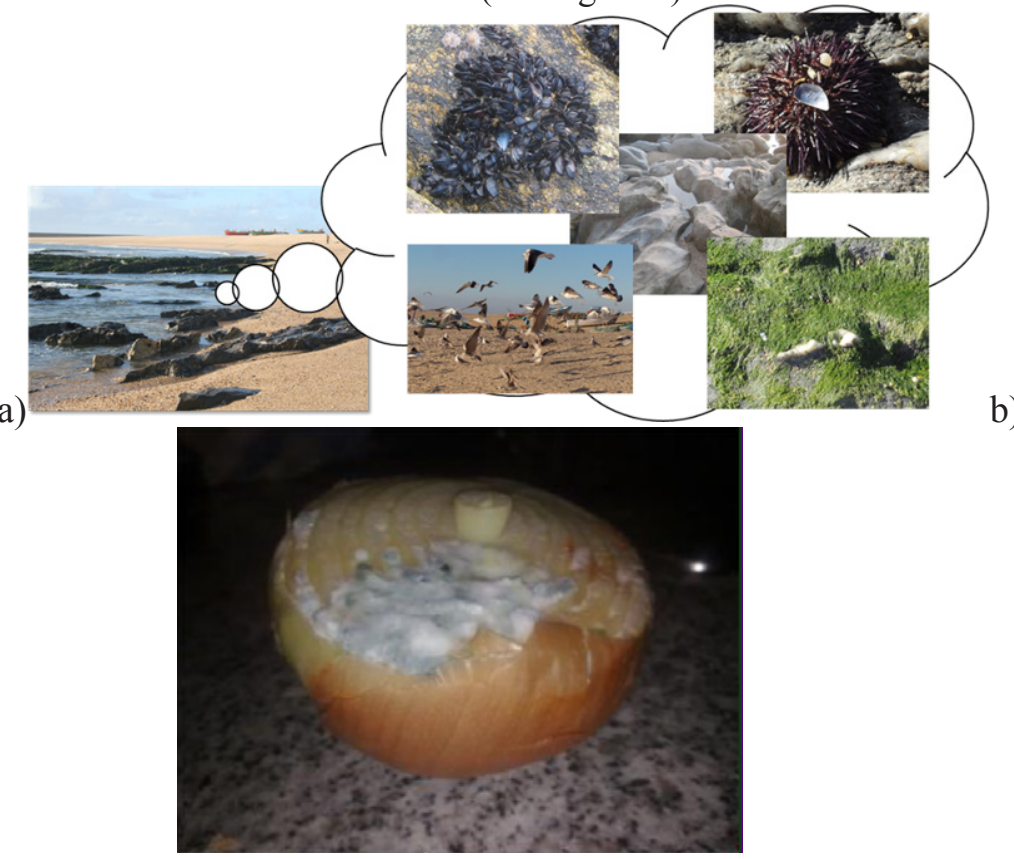

b)

\section{Figure 1. Children's photographs of a tide pools ecosystem and of a rotten on- ion.}

In order to familiarize children with specific natural objects and phenomena, the sensory observation and the production of multiple representations of the manifestations of such objects and phenomena were used in several circumstances. For instance, by: (a) observing microbes in diverse photos and contexts (CS1; CS6); (b) sensing, with their hands, the temperature of water in varied controlled circumstances (CS3); listening multiple sounds and feeling (touch) other environmental vibrations (CS4); observing multiple experiments related to the production of carbon dioxide in a sensory active way (CS5).

The digital photos (CS2; CS6) and the children's drawings of the microscopic observations (see CS1; CS6), as well as the graphics produced automatically by the other electronic sensors, with the data acquired during children's activities, were used as bridges between the more abstract variables and the sensory experiences of children. The photos were classified to study biodiversity (CS1; CS2) and zonation (CS2) concepts, and also the food conservation topic and its relation to microbes and hygiene (CS6). The graphics were explored by children with the support of teachers, looking for the variation of dependent variables as a function of independent variables (CS2; CS3; CS5). For instance, in CS4, children used the sense of touch to monitor their own cardiac rhythm and to understand such variable. They noticed the different cardiac rhythm of the different students. A child stated that " $\mathrm{X}$ said that when she gets frightened her heart beats stronger". They proceed, discussing the relations between emotions and cardiac rhythm. Afterwards, the children were able to use the cardiac rhythm sensor and to interpret the graphics it produced automatically with the data acquired. Children were able to notice the variations of the sensed cardiac rhythm and to relate them with the emotions provoked by diverse sounds (CS4).

This way, when analysing the more abstract data acquired by the sensors, as for instance cardiac rhythm (CS4, as described in the previous paragraph), and temperature (see CS2 and CS3 in Table 3), the previous and related children's multisensory experiences scaffolds the 
interpretation of such data, by bridging concreteness and abstraction.

\section{Scaffolding in Teachers-Children-Sensors Interactions}

The topics addressed in all the case studies are complex (see Table 2). Considering the age of the participant children, those topics could only be learned using teacher scaffold. Moreover, in all the case studies teachers promoted class discussions in order to create a shared repertoire about: the problem/questions to be investigated; the planning of the experiments; the formulation of hypotheses; the interpretation of what happened in the experiments; and the generation of new questions.

None of the case studies used initial activities to discuss the cases' general problem/ questions. However, several of the initial activities assessed the children's previous ideas about the topic and may have worked as advanced organizers that subsume the general problem/ questions. In CS2, the teacher-researcher promoted a dialogue, asking children about their previous knowledge and experiences in what concerns the local tide pools ecosystem. The teacher-researcher of CS1 used an oral questionnaire, answered by children in a class debate, to make explicit the children's previous ideas about the topics Biodiversity and Living Being. The questionnaire included questions such as: (a) "Give examples of living beings that you know?"; (a) "Where did you those living beings?"; (c) "Do you know all the living beings of the world?". The children were then asked to draw illustrations of living beings. The teacherresearcher of CS3 used a written questionnaire to asses the ideas of children in what concerns thermal equilibrium. The teachers-researchers of CS5 and CS6 also used oral questionnaires that were implemented using focus group techniques to understand what children already knew about photosynthesis and the carbon cycle (CS5) and about the microbes and their relations to food conservation (CS6).

Furthermore, at the beginning of some of the experimental situations, the teachersresearchers promoted the discussion of the specific problem/questions. Examples of such problem/questions are: "Are there living beings in this pond water?" (CS1); "How does the temperature of the water vary during the day in our classroom?" (CS2); "How would the carbon dioxide concentration in the air of a closed environment that contains a plant vary with luminosity?"(CS6). In CS2, children have made predictions and have justified their predictions by making explicit the involved cause-effect relations (11 of the 23 children stated that the water temperature would vary, due to the influence of the sun). Both in CS1 and CS2, children identified the procedures needed to verify their predictions. On the other hand, in CS5 children have made predictions, but the involved cause-effect relations were only identified after the experiment, in the interpretation phase (see Table 5).

The experiment plans, as tools to make scientific strategies explicit and visible, were only used in CS2. However, teachers-researchers used observation tables and charts that asked children to record, information acquired by senses and sensors, using multiple formats and separating observations from interpretation and estimative.

In CS2, the groups of children, after a class discussion about the experiment with the mediation of the teacher, were able to fill the experiment plan form, identifying the specific problem/question, the variables to change, to monitor, and to maintain, the procedures, and the needed resources. On the other hand, teachers-researchers used observation tables and charts that asked children to record, information acquired by senses and sensors, using multiple formats and separating observations from interpretation and estimative (see Table 5). 
Maria João SILVA, Joaquim BERNARDINO LOPES, António Alberto SILVA. Using Senses and Sensors in the Environment to Develop Abstract Thinking - a Theoretical and Instrumental Framework

OF EDUCATIC

IN THE $21^{\text {st }}$ CENTURY

Volume 53, 2013

Table 5. Examples of the use of observation and interpretation forms

\begin{tabular}{|c|c|c|}
\hline Case Study & Observation and Interpretation Forms & Results \\
\hline CS1 & $\begin{array}{l}\text { Observation tables that asked children } \\
\text { to draw microorganisms and cells of } \\
\text { macro-organisms observed with diverse } \\
\text { magnifications with the optical and digital } \\
\text { microscope (see image in Table 3) }\end{array}$ & $\begin{array}{l}\text { From the first to the fourth activity, children improved } \\
\text { their observations and drawings. At the first activity, } \\
\text { many of the drawings made by children didn't repre- } \\
\text { sent accurately what was observed. These problems } \\
\text { disappeared gradually with the training and practice } \\
\text { offered by the fourth activities. }\end{array}$ \\
\hline CS2 & $\begin{array}{l}\text { During the classroom water temperature } \\
\text { monitoring experiment, children were } \\
\text { asked to register the temperature data } \\
\text { acquired by the temperature sensor and to } \\
\text { draw graphics based on those data values. }\end{array}$ & $\begin{array}{l}\text { Children, working in groups, were able to register, at } \\
\text { pre-defined times, the water temperatures sensed } \\
\text { by the sensor and to draw graphics, based on those } \\
\text { data. However, only some of the children's graphics } \\
\text { were significantly similar to the ones automatically } \\
\text { produced by the sensors. }\end{array}$ \\
\hline CS3 & $\begin{array}{l}\text { Children were invited to fill a table with } 3 \\
\text { columns: time; prediction of water tempera- } \\
\text { ture; measured temperature. }\end{array}$ & $\begin{array}{l}\text { Children were able to fill the table with their predic- } \\
\text { tions and with the thermometer data. At the final } \\
\text { phase of the experiment, their predictions were } \\
\text { improved (see Table 4). }\end{array}$ \\
\hline CS5 & $\begin{array}{l}\text { In the experiment to study how the carbon } \\
\text { dioxide concentration in the air of a closed } \\
\text { environment that contains a plant vary with } \\
\text { luminosity, the report form that children } \\
\text { were asked to fill separate and identify the } \\
\text { questions regarding predictions, data col- } \\
\text { lection, data analysis, and data interpreta- } \\
\text { tion }\end{array}$ & $\begin{array}{l}\text { The majority of children were able to predict that the } \\
\text { carbon dioxide concentration will decrease with the } \\
\text { presence of light and increase without light. } \\
\text { In the interpretation, they were also able to relate } \\
\text { the diminishing of carbon dioxide concentration with } \\
\text { the photosynthesis. However, children's answers } \\
\text { to data analysis and data interpretation questions } \\
\text { showed that they didn't completely understand how } \\
\text { photosynthesis is related with respiration. }\end{array}$ \\
\hline
\end{tabular}

As described in Table 5, although in an exploratory way and in different depths (given the different ages of children and the heterogeneity of the case studies), the use of those observation and interpretation forms in the mentioned activities contributed to familiarize children with: (a) environmental variables and their units (since children performed multiple tasks that included sensory observations, measurements using sensors, creation of different registers - filling tables and drawing graphics - analysis and interpretations of such registers); (b) different procedures and methods of science inquiry, such as prediction, observation and interpretation.

In two of the case studies (CS2; CS5), the teachers-researchers scaffolded children's interpretation of complex graphics (automatically produced with the use of sensors and representing the variation of environmental variables in a continuous way). To scaffold such interpretation, teachers mapped parts of the graphics with children's actions and sensory information, creating concrete annotations that identified: (a) Parts of the graphic with hours of the day. These annotations scaffold interpretation, since the X axis' units were seconds; (b) Actions during the experiment, such as the exhalation over the carbon dioxide sensor or the opening of the window. These annotated graphics make it simpler to understand the diminishing of carbon dioxide concentration when the window was opened, using concreteness fading and making it possible to understand what happened while overcoming the abstraction of carbon dioxide concentration units, for instance. 
a)

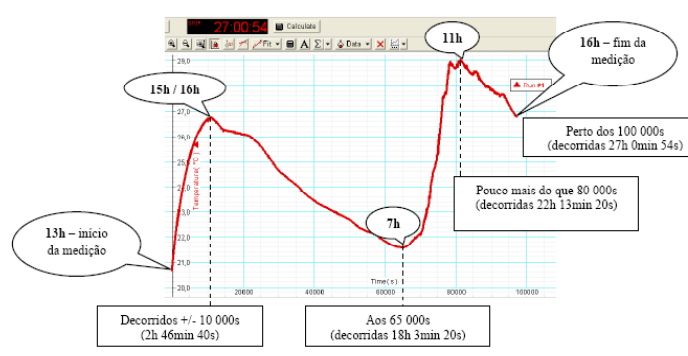

b)

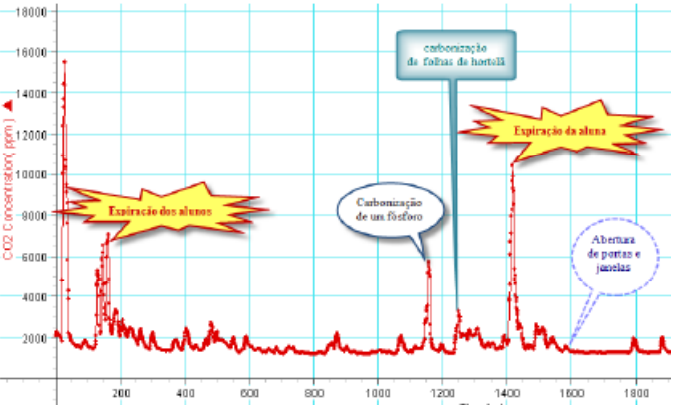

Figure 2. Examples of graphics automatically produced with the data acquired by the sensors and annotated to scaffold children in the interpretation tasks in CS2 (a) and CS5 (b).

Translation: a) Squared annotations - time in seconds transformed to hours, minutes and seconds; oval annotations - measurement's hour of the day (Início da medição - beginning of the measurements; Fim da medição - End of the measurements); b) annotations from left to right: student exhalation over the sensor; carbonization of a match; student exhalation over the sensor; Opening of doors and windows.

Concreteness fading can also scaffold the development of abstract thinking. In CS1, the digital microscope made it possible for children to control the continuous magnification of the organisms in observation. This way, children could proceed from the concrete observation of reality (vision without tools), increasing magnification in a continuous way, and thus fading concreteness towards the microscopic world (unobservable and consequently more abstract). Children's drawing showed that they could bridge these two worlds. In CS2, in order to study the abstract concept of zonation, learning activities started with the in-situ tide pools sensory exploration (using vision, hearing, smell and touch). Subsequently, and appealing for children's sensory memories and registers (digital photos and sounds), learning activities proceed with the exploration of a virtual tide pool and the construction of two and three dimensional models of that ecosystem, where children were able to represent zonation. In the same way, the use of digital cameras by children, to produce sensory registers of everyday phenomena, scaffolded the learning of the complex concepts of microbes, food conservation and hygiene (CS6).

In the study of temperature (CS3), the sensory exploration of water temperature and the juxtaposition of the children's estimations with the quantitative measurement of temperature made it possible for children to make sense of the temperature sensor's graphics that hold increased complexity and abstraction. Likewise, in CS4 and CS5, children's understanding of the measurements displayed by the cardiac rhythm sensor, the sound level sensor and the carbon dioxide sensor was rooted on their sensory experiences and actions.

\section{Epistemic Practices as Indicators of the Development of Abstract Thinking}

Considering the exposed in the preceding sections, it is possible to state that in the case studies, children performed numerous and significant epistemic practices while using senses and sensors to explore complex environmental phenomena. The use of sensors as extensions of senses, and the use of senses to scaffold the use of sensors (affording abstract learning), supported children in autonomous sense making operations, such as the ones explained in Table 6. 
Maria João SILVA, Joaquim BERNARDINO LOPES, António Alberto SILVA. Using Senses and Sensors in the Environment to Develop Abstract Thinking - a Theoretical and Instrumental Framework

OF EDUCATION

IN THE $21^{\text {st }}$ CENTURY

Volume 53, 2013

\section{Table 6. Examples of observed epistemic practices}

\begin{tabular}{|c|c|c|}
\hline $\begin{array}{l}\text { Examples of Epistemic } \\
\text { Practices }\end{array}$ & Explanation & Examples of evidences \\
\hline $\begin{array}{l}\text { Observing/sensing: } \\
\text { The children, with teacher } \\
\text { mediation, focus their atten- } \\
\text { tion on specific objects or } \\
\text { phenomena with or without } \\
\text { sensors }\end{array}$ & $\begin{array}{l}\text { Observing/sensing the sensorially observ- } \\
\text { able, such as macro-organisms (CS1; CS2), } \\
\text { temperature changes (CS3), sounds (CS4) } \\
\text {, cardiac rhythm (CS4), food appearance } \\
\text { (using vision and smell) (CS6), as well as the } \\
\text { sensorially unobservable, such as microor- } \\
\text { ganisms (CS1; CS6) or carbon dioxide in the } \\
\text { atmosphere (CS5), using sensors as exten- } \\
\text { sions of senses; }\end{array}$ & $\begin{array}{l}\text { See images of Table } 3 \text { : Those } \\
\text { drawings confirm that children have } \\
\text { observed microorganisms in an } \\
\text { adequate way. } \\
\text { See Figure 1: The children's photos } \\
\text { confirm the adequacy of the obser- } \\
\text { vations. }\end{array}$ \\
\hline $\begin{array}{l}\text { Describing: } \\
\text { The children, with teacher } \\
\text { mediation, collect and } \\
\text { use acquired information } \\
\text { to characterize, (through } \\
\text { registers, reports, drawings, } \\
\text { etc.) objects or phenomena; }\end{array}$ & $\begin{array}{l}\text { Describing environmental situations, based } \\
\text { on information acquired by senses but also } \\
\text { by the sensors. Those sensors recorded the } \\
\text { sensory information (e.g. digital photos and } \\
\text { sounds acquired by mobile phones) (CS2; } \\
\text { CS6) quantified and produced numeric and } \\
\text { graphical representations (in a discrete } \\
\text { or continuous way) of variables such as } \\
\text { temperature (CS2; CS3), carbon dioxide } \\
\text { concentration (CS5), sound level and cardiac } \\
\text { rhythm (CS4). }\end{array}$ & $\begin{array}{l}\text { For instance, in CS3, a child de- } \\
\text { scribed a table with } 3 \text { columns (time; } \\
\text { prediction of water temperature; } \\
\text { measured temperature): "In the first } \\
\text { prediction, my value was superior } \\
\text { [to the measured one], but in the } \\
\text { following predictions, I noticed that } \\
\text { the measured temperature rised } 2^{\circ} \mathrm{C} \\
\text { from } 5 \text { to } 5 \text { minutes..." }\end{array}$ \\
\hline
\end{tabular}

Interpreting the recorded data and information: The children, with teacher mediation, explain the meaning of objects, or phenomena based in their previous descriptions;
Examples of such practices are: organizing and classifying digital photos (CS2; CS6), reading discrete values and continuous graphics produced by sensors (CS2; CS3; CS4; CS5), interpreting graphics, tables, drawings and other recordings produced by themselves, while relating the variation of dependent variables to the variation of independent variables (CS2; CS3; CS4; CS5). These epistemic practices were scaffolded by observation tools, such as experiment report forms (CS1; CS2; CS4; CS5; CS6) and by the mapping/bridging of abstract representations with children's sensory experiences (CS2; CS5).

Controlling variables: The children, with teacher mediation, implement the planned procedures to maintain control variables, change independent variables and monitor dependent variables
Controlling variables, such as seeing the same organism with different magnifications (CS1), choosing the local in the classroom to place the goblet with water to monitor the temperature in $24 \mathrm{~h}$ (CS2), measuring the temperature of a glass of water at different depths (CS3), monitoring the sound level while augmenting the distance from the sound source (CS4), monitoring carbon dioxide concentration in the air of a closed environment that contains a plant while changing the light conditions (CS5).
A child (CS4) described the graphic produced with the cardiac rhythm sensor (cardiac rhythm vs time), used by another child while hearing different music: "During the first music [the lines] are all up. During the second music, are all up and down. And during the Shakira song are all up. It overcame 100 once" (CS4). Finally, s/he expressed the following statement: "She liked more the first and third music".

In CS3, the groups of children measured the temperature of the water in a glass (see illustration below), placing the thermometer immediately below the surface and at the bottom.

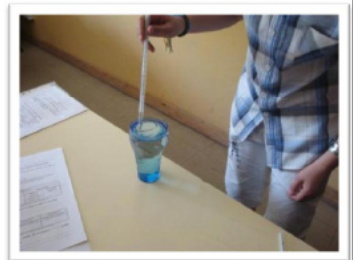

See Table 3 for other examples of situations in which variables were controlled by children. 

sentations: The children, with teacher mediation, create pictorial and symbolic representations of objects or phenomena
Creating multiple representations, such as drawings (CS1; CS2; CS5; CS6), three dimensional models (CS2), tables (CS2; CS3; CS4), graphics (CS 2; CS3; CS4), diagrams (CS1; CS5) and small texts (CS3; CS5). Those representations are a result of the use of sensors and are part of the sense making process. Such creation affords reflection and scaffolds modelling the relations between variables.
Modelling: The children, with teacher mediation, create conceptual representations of objects, or phenomena, using a given kind of language.
Children, with the mediation of teachers, were able to create very simple models such as constructing a conceptual model of a living being (CS1), relating and representing different species to different zones of the seashore (CS2). However, in the other case studies only occurred the first phase of conceptual modelling that is the recognition and establishment of relations between variables and concepts, such as: conceiving the sensation of temperature as the gain or loss of heat (CS3); relating cardiac rhythm to emotions (CS4), relating photosynthesis, carbon dioxide and the carbon cycle (CS5), and relating microbes to food conservation (CS6).
See Tables 3 and 4 for examples of pictorial and symbolic representations created by children.
PROBLEMS

OF EDUCATION

IN THE $21^{\text {st }}$ CENTURY

Volume 53, 2013
In CS2, children were able to complete meaningfully 2 (see illustration below) and 3 dimensional models of a tide pool zonation.

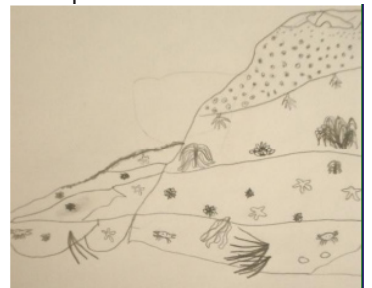

In CS3, some of the children said that the hands are not an accurate way of perceiving temperature. They explained that when they put in the tepid water the hand that was in the hot water it lost heat. And that when they put in the tepid water the hand that was in the cold water it gained heat. And that was why the sensation of temperature was different in each hand.

It is noteworthy that the experiment planning practices (identify and select the conditions in which the phenomena will occur), such as selecting variables and the planning of procedures were only developed by children in CS2. In the other case studies, those planning practices were developed by the teachers-researchers. In the classroom water temperature monitoring experiment (CS2), the children, with the mediation of the teacher, were able to identify the specific variables that will change (sun radiation and time), the variables to monitor (temperature), and to maintain (the goblet, the water volume, and the position of the temperature sensor). They were also able to identify and the resources and procedures to be used (see Figure 3). In CS2, as in the other case studies, children were able to implement procedures with the mediation of the teacher. 
OF EDUCATION

IN THE $21^{\text {st }}$ CENTURY

Volume 53, 2013

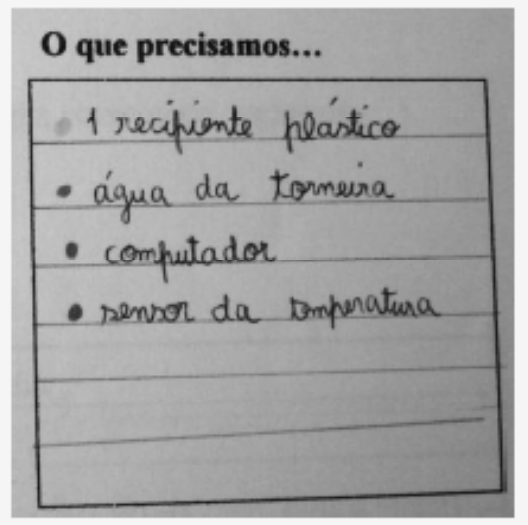

Legend (translation): $1^{\text {st }}$ excerpt - what we need - 1 plastic container; tap water; computer; temperature sensor; $2^{\text {nd }}$ excerpt - what we are going to do.

Figure 3. Excerpts of a filled experiment plan form (CS2).

\section{Discussion}

In the analyzed case studies, children from the $2^{\text {nd }}$ to the $6^{\text {th }}$ year of scholarity used diverse sensors to collect environmental data, such as temperature, carbon dioxide concentration and sound level. Moreover they used sensors (such as mobile phones, netbooks, and digital cameras) to produce photos and to record sounds, and they also used a digital microscope to observe living beings, travelling along different semiotic registers (from a macroworld to a microworld). Those uses of sensors took place in the context of meaningful environmental education inquiry activities aiming at solving diverse problems, which confirmed the affordances presented by Le Boniec and colleagues (2012).

Children used the sensors in a heterogeneous way. Although all the children implemented with efficacy the procedures necessary to the correct use of sensors, some children showed more difficulties than others, for instance in: relating the acquired data with associated concepts, namely linking different semiotic registers as macro and micro point of views when using microscopes; and in interpreting some abstract graphics produced with the data acquired by sensors. This kind of difficulties is reported by diverse authors as stated in Reiser (2004).

Human senses, such as vision, hearing, touch, and sense of temperature, scaffolded the use of sensors and the tasks of making sense of such uses. Children senses were used to adjust the placement, position, and other conditions in the use of sensors. Furthermore, according to Reiser (2004), children's actions and sensory experiences were successfully used as a concrete basis to more abstract learning activities (using sensors and making sense of the acquired data).

To scaffold the joint use of senses and sensors, teachers applied a set of specific strategies. In order to engage children in authentic activities, teachers tried to ensure the appropriation by children of the diverse dimensions of the specific inquiry activities (Quintana et al., 2004). In the analyzed case studies, teachers promoted in-depth class discussions to create a shared repertoire about problems/questions, what to do, what happened... The development of experiment plans with the children was only implemented in one case study, but it showed to be a useful strategy in supporting children in the development of inquiry tasks, which is consistent with the stated by Martins et al. (2007), and in transferring responsibility to students (Van de Pol et al., 2010).

In addition, the observation forms that called for the creation of recordings using multiple representations of senses and sensors data (while separating observations from interpreta- 
tion and estimative) showed to be useful in scaffolding the sense making of phenomena and their representations that other way would be too complex to be addressed by children of those

ages (Quintana et al., 2004; Reiser, 2004).

Concreteness fading (Goldstone, \& Son, 2005) was another strategy used by teachers to scaffold abstract learning. For instance, teachers created bridges from the concrete sensorial experiences and from children's point of view to more abstract point of views (with the digital microscope) and to more abstract representations (graphics with sensors data annotated with sensorial experiences). These strategies reduced the complexity of the tasks and improved abstract learning (Norman, 1991; Quintana et al., 2004; Reiser, 2004; Rogers, et al., 2010).

Our results show that the joint use of sensors and senses, mediated by teachers, scaffolded children in: (a) focusing their attention on pertinent aspects of objects or phenomena; (b) giving actual opportunities to collect and use information to characterize what had been previously observed; (c) searching for regularities and patterns; (d) triggering the use of multiple representation of objects and phenomena. Thus, the sensors can be used to improve, directly, some epistemic practices, namely, observing, describing, controlling variables, and multiple representations. If it is noted that the observation (to focus the attention) and the description (to collect and use information to characterize) are the first steps of the abstraction pathway in inquiry practices, it is understandable why our results show an improvement of interpreting epistemic practice. In fact, the interpretation is the first phase of the abstraction pathway, in which students attempt to give meaning to what had been described. Based on the results, it is possible to conjecture that observation and description are very important steps for that. Also, it was found that the sensors have an important role in controlling variables and in multiple representations. However, its influence on modelling epistemic practice is moderate. In fact, modelling is a complex task that requires knowledge and skills that need time to be developed (Lopes, 2011). In synthesis, the used strategies and resources created conditions for having some relevant epistemic practices that allow the development of abstract learning, even if at the ages of the participant children (from seven to twelve) abstract thinking is not yet fully developed.

The above discussion about the results of the use of the "framework to inform the design and the assessment of the use of senses and sensors to develop abstract thinking" allows the authors to present it in a more specific and grounded formulation (Table 7). 
Maria João SILVA, Joaquim BERNARDINO LOPES, António Alberto SILVA. Using Senses and Sensors in the Environment to Develop Abstract Thinking - a Theoretical and Instrumental Framework

PROBLEMS

OF EDUCATION

IN THE $21^{\text {st }}$ CENTURY

Volume 53, 2013

114

Table 7. Framework to inform the design and the assessment of the use of senses and sensors to develop abstract thinking.

\begin{tabular}{|c|c|c|c|}
\hline Dimensions & Rational & Sub-dimensions & Rational \\
\hline \multirow{5}{*}{$\begin{array}{l}\text { 1. Children's } \\
\text { use of sensors }\end{array}$} & \multirow{5}{*}{$\begin{array}{l}\text { The sensors are extensions } \\
\text { of human senses. } \\
\text { They offer multiple envi- } \\
\text { ronmental experiences to } \\
\text { children, scaffolding the } \\
\text { interpretation of abstract } \\
\text { data and of multiple repre- } \\
\text { sentations. } \\
\text { Sensors help children to fo- } \\
\text { cus on the relevant aspects } \\
\text { of a phenomenon, support- } \\
\text { ing them in autonomous } \\
\text { sense making operations. } \\
\text { Addressing a specific } \\
\text { environmental phenomenon } \\
\text { requires the selection of an } \\
\text { adequate set of sensors. }\end{array}$} & $\begin{array}{l}\text { 1.1 Children's aware- } \\
\text { ness about the diverse } \\
\text { sensors and their func- } \\
\text { tions; }\end{array}$ & $\begin{array}{l}\text { The current and widespread diversity } \\
\text { of sensors offers opportunities and } \\
\text { means for children to explore multiple } \\
\text { environmental information }\end{array}$ \\
\hline & & $\begin{array}{l}1.2 \text { Looking for effective } \\
\text { uses of sensors; }\end{array}$ & $\begin{array}{l}\text { The use of each sensor calls for a } \\
\text { search for adequate use conditions, } \\
\text { such as magnification, location, point } \\
\text { of view, position and operation; }\end{array}$ \\
\hline & & $\begin{array}{l}1.3 \text { Children's aware- } \\
\text { ness about environmen- } \\
\text { tal information obtained } \\
\text { by sensors (Le Boniec, } \\
\text { Gras-Velázquez \& Joyce } \\
\text { 2012); }\end{array}$ & $\begin{array}{l}\text { The use of sensors add new meanings } \\
\text { to children's sensory observation } \\
\text { of the properties of natural objects } \\
\text { and phenomena, contributing to an } \\
\text { enhanced (more informed) use of } \\
\text { human senses. Sensors scaffolds } \\
\text { children in focusing in key aspects of } \\
\text { environment. }\end{array}$ \\
\hline & & $\begin{array}{l}\text { 1.4 Production of envi- } \\
\text { ronmental information } \\
\text { recordings; }\end{array}$ & $\begin{array}{l}\text { Sensors can be used to produce } \\
\text { multiple environmental information } \\
\text { recordings, such as photos, recorded } \\
\text { sounds and videos. Graphics can be } \\
\text { automatically produced by sensors } \\
\text { that are linked to data loggers. }\end{array}$ \\
\hline & & $\begin{array}{l}1.5 \text { Search for informa- } \\
\text { tion obtained only by } \\
\text { sensors; }\end{array}$ & $\begin{array}{l}\text { Using sensors, children can under- } \\
\text { stand and compare what it is possible } \\
\text { to sense with sensors and with human } \\
\text { senses; }\end{array}$ \\
\hline
\end{tabular}


2. Children's use of senses, and sensorial information

3. Scaffolding

in Teachers-

Children-Sensors Interactions
The human senses offer a concrete basis to make sense of sensors' data, since children use senses to explore environmental objects and phenomena. In particular, the senses (and multisensory information) can be used by children to explore and contro the adequate conditions to use sensors.

Teacher mediation can contribute to improve the understanding of science inquiry steps, of data patterns and relations, and of the mapping between tool's representations, what they represent and children's point of view.

Teachers can gradually transfer responsibility to children, while supporting them in the identification and selection of the conditions in which the phenomena should occur, such as selection of the independent and dependent variables and planning of procedures
Children can control the use of their

2.1 Control of sense data (Reiser, 2004); sense of temperature...) as well as the data to be acquired, by searching for the more adequate use conditions, such as location, point of view, and point of hearing...;

Sensory observation, in several cir-
2.2 Familiarization with cumstances, familiarize children with natural phenomena, the properties of natural objects and enhancing concreteness phenomena, building concrete experi(Reiser, 2004); ences that can constitute a basis to make sense of sensors' data

2.3 Search for consistent information (Reiser, 2004);

Comparisons between sensory assessments and the sensors' data scaffold children at enhancing the use of senses and sensors.

Teacher mediation can promote the creation of a shared repertoire, in 3.1 Discussing what what concerns: the problem/questions to do, what happened, to be investigated; the planning of why happened, what will the experiments; the formulation of happen... hypotheses; the interpretation of what happened in the experiments; and the generation of new questions.

Tools such as experiment plans, observation tables and charts can help students to be aware of the need to separate observations from interpretation and estimative. They require records of senses and sensors in

3.2 Making scientific strategies visible (Quintana et al., 2004): multiple formats and should separate observations from interpretation or predictions..

Teachers can scaffold the use of those tables and charts to improve children's understanding of data patterns and of relations between variables.

3.3 Mapping/Bridging representations, including concreteness fading (Goldstone, \& Son, 2005)

3.4 Using descriptions of complex concepts/ phenomena that build on authentic and sensory experiences Quintana et al., 2004)
Teachers can proceed from concrete sensory observation of reality and fading concreteness towards more abstract representations.

Teachers can scaffold the interpretation of complex representations through the mapping of parts of complex representations with children's actions and sensory information, using concrete annotations that overcome abstraction. 
Maria João SILVA, Joaquim BERNARDINO LOPES, António Alberto SILVA. Using Senses and Sensors in the Environment to Develop Abstract Thinking - a Theoretical and Instrumental Framework

\begin{tabular}{|c|c|c|c|c|}
\hline $\begin{array}{r}\text { PROBLEMS } \\
\text { OF EDUCATION } \\
\text { IN THE } 21^{\text {st }} \text { CENTURY } \\
\text { Volume } 53,2013\end{array}$ & & & & \\
\hline 116 & $\begin{array}{l}\text { 4. Epistemic } \\
\text { practices }\end{array}$ & $\begin{array}{l}\text { Evidences of the use in } \\
\text { practices which need ab- } \\
\text { stract thinking, as a result } \\
\text { of the joint use of senses } \\
\text { and sensors and as indica- } \\
\text { tors of the development of } \\
\text { abstract thinking }\end{array}$ & $\begin{array}{l}\text { 4.1 Observing/sensing } \\
\text { 4.2 Describing; } \\
\text { 4.3 Interpreting; } \\
\text { 4.4 Controlling variables; } \\
\text { 4.5 Creating multiple } \\
\text { representations; } \\
\text { 4.6 Modelling. }\end{array}$ & $\begin{array}{l}\text { Use of senses and sensors can } \\
\text { enhance observation and description, } \\
\text { facilitating deeper interpretations. Sen- } \\
\text { sors can constitute an instrumental } \\
\text { basis to control variables and to create } \\
\text { multiple representations, fostering the } \\
\text { more complex modelling practices. }\end{array}$ \\
\hline
\end{tabular}

As stated before, the four dimensions of the framework are articulated. The two first dimensions, together, allow the analysis of how children use senses and sensors, and how they articulate them to improve the understanding of the phenomena. They also give to teachers insights about how to introduce senses and sensors in learning activities. The third dimension should be viewed as the necessary teacher effort for an effective use of senses and sensors, contributing to the development of abstract thinking. The dimension about epistemic practices allows teachers and researchers to know if, how and why abstract thinking has been developed.

\section{Conclusions}

The research presented in this paper addressed the potential of the joint use of senses and sensors to improve the development of abstract thinking in the context of hands-on authentic inquiry activities. The review of the literature and of the previous work was the base to propose a brief formulation of the framework. Using 3 guiding questions and this framework, a crossanalysis of 6 case studies was used to illustrate the usability of the framework, as well as to explain how each dimension works and how the articulation among them can take place.

The results of the cross-analysis allow the following highlights:

(a) Children used senses, such as vision, hearing, touch, and sense of temperature, to explore diverse environmental objects/phenomena and variables, as living beings, water temperature, sounds, and cardiac rhythm. Those senses were also used by children to explore and control the adequate conditions to use sensors. The joint use of senses and sensors made it possible to observe what is unobservable to human senses, such as microbes and carbon dioxide concentration in the air. It also made possible to produce recordings of several type (photos and sound recordings graphics of data acquired by senses and automatically created). Sensors were used as extensions of human senses and senses offered a concrete basis to make sense of sensors' data.

(b) The teachers-researchers used a series of strategies to scaffold children in the use of senses and sensors to develop children's abstract thinking, such as: i) Making scientific strategies visible, to ensure that children made sense of the diverse dimensions of the specific inquiry activities. Experiment plans and observation tables and charts that separate observations from interpretation and estimative were important tools in this context; ii) Mapping/bridging representations, namely through the use of concreteness fading, linked for example more abstract sensors' data graphics with children's actions and everyday sensorial experiences;

(c) By using senses and sensors in the context of environmental education with authentic activities, children developed epistemic practices such as observing, describing, interpreting, controlling variables, and creating multiple representations. Modelling was the less observed epistemic practice, which seems to point to the need for an emphasis and improvement of teacher mediation in relation to this dimension.

The above statements show that the proposed framework, now in a more specific and grounded formulation, as a result of the cross-analysis, can be used to inform the design of learning activities that use senses and sensors to develop abstract thinking, and to assess how abstract thinking was actually developed in those learning activities.

This framework will be used in the SOS Abstract research project to guide the design and the analysis of future case studies, in order to continue and to improve the theorization process. 
Since developing abstract thinking is not an easy task, it is possible that more aspects will be considered in the next phase of the theorization process. This framework will be also used in teachers training and in teachers' professional development.

\section{References}

Brites, R., Calado, A., Estêvão, P., Carvalho, J. M., \& Conceição, H. (2011) Estudo de Avaliação e Acompanhamento dos Ensinos Básico e Secundário: Relatório Final. Lisboa: ISCTE; IUL.

Brown, J., Collins, A., \& Duguid, P. (1989) Situated cognition and the culture of learning. Educational Researcher, 18 (1), 32-42.

Chinn, C. A., \& Malhotra, B. A. (2002). Epistemologically authentic inquiry in schools: a theoretical framework for evaluating inquiry tasks. Science Education, 86 (2), 175-218.

Cohen, L., Manion, L., \& Morrison, K. (2007). Research Methods in Education (6th Ed.). London: Routledge.

Fenton, M. (2008). Authentic learning using mobile sensor technology with reflections on the state of science education in New Zealand: A research project for the New Zealand Ministry of Education. Taranaki, New Zealand: Nexus Research Group. Retrieved 10/02/2013, from http://www.nexusresearchgroup.com/downloads/Michael-Fenton-eLearning-Report.pdf

Figueiredo, A. D. (2005). Learning contexts: A blueprint for research. Interactive Educational Multimedia, 11, 127-139.

Goldstone, R., \& Son, J. (2005). The Transfer of Scientific Principles Using Concrete and Idealized Simulations. Journal of the Learning Sciences, 14 (1), 69-110.

Gonçalves, L. (2012). Ensino experimental da biodiversidade e da temperatura nas poças de maré: Uma proposta pedagógica para o $4^{\circ}$ ano de escolaridade. Relatório de Projeto de Mestrado. Porto: Escola Superior de Educação do IPP.

Heggen, S., Omokaro, O., \& Payton, J. (2012). Mad Science: Increasing engagement in STEM education through participatory sensing. In Proceedings of the Sixth International Conference on Mobile Ubiquitous Computing, Systems, Services and Technologies (UBICOMM 2012). New York: ACM.

Henning, P. (2004). Everyday cognition and situated learning. In D.H. Jonassen (Ed.), Handbook of Research on Educational Communications and Technology. Mahwah, New Jersey: Lawrence Erlbaum, pp. 143-168.

Hilton, M. (2010) Exploring the Intersection of Science Education and 21st Century Skills: A Workshop Summary. National Research Council The National Academies Press. Retrieved 10/04/2012, from http://www.nap.edu/catalog.php?record_id=12771

Knight, S. (2005). Innovative Practice with e-Learning. Bristol: Higher Education Funding Council for England.

Le Boniec, M., Gras-Velázquez À., \& Joyce A. (2012). Impact of data loggers on science teaching and learning. Brussels: European Schoolnet. [In collaboration with Fourir and Acer]. Retrieved 06/02/2013, from http://files.eun.org/netbooks/ACER_Fourier_EUN_Science_pilot_report_2012. pdf

Leão, N. (2011). Fotossintese e ciclo do carbono no ensino das ciências no $6^{\circ}$ ano: Utilização de sensores. Relatório de Projeto de Mestrado. Porto: Escola Superior de Educação do IPP.

Lockitt, B. ( 2005 ). Mobile learning. 3T Productions Limited .

Lopes, J. B., Cravino, J. P., Silva, A. A., Viegas, C., Cunha, A. E., Saraiva, E. et al. (2010). Investigação sobre a mediação de professores das Ciências Físicas em sala de aula. Vila Real: Universidade de Trás-os Montes e Alto Douro.

Lopes, J. B. (2011). Pathways of students' conceptualisation during a problem solving task: lessons for teaching physics. Journal of Baltic Science Education, 10 (1), 36-52.

Lopes, J. B., Cravino, J. P., Silva, A. A., Viegas, C. (2012). The role of teacher mediation using computer simulations in physical sciences to improve students' epistemic competences - a theoretical framework. In Computer Based Learning In Science. Conference Proceedings 2012 (pp. 2-10). Retrieved 30/01/2013, from http://cblis2012.crecim.cat/proceedings/

Magnani, L. (2004). Reasoning through doing. Epistemic mediators in scientific discovery. Journal of Applied Logic, 2 (4), 439-450. 
Maria João SILVA, Joaquim BERNARDINO LOPES, António Alberto SILVA. Using Senses and Sensors in the Environment to Develop Abstract Thinking - a Theoretical and Instrumental Framework

PROBLEMS

OF EDUCATION

IN THE $21^{\text {st }}$ CENTURY

Volume 53, 2013

118

Martins, I., Veiga, M. L., Teixeira, F., Tenreiro-Vieira, C., Vieira, R. M., Rodrigues, A. V., Couciero, F. (2007). Educação em ciências e ensino experimental: Formação de professores. Lisboa: Curricular Ministério da Educação, Direcção-Geral de Inovação e de Desenvolvimento.

Mason, J., \& Davies, K. (2009). Coming to our senses? A critical approach to sensory methodology. Qualitative Research, 9 (5), 587-603.

Minogue, J., \& Jones, M. G. (2006). Haptics in Education: An Untapped Sensory Modality. Review of Educational Research, 76 (3), 317-348.

Moreira, D. (2011). "A Microbiologia e a conservação de alimentos": Uma abordagem experimental das Ciências, numa turma de $6^{\circ}$ ano da Escola E.B. 2,3 Passos José. Relatório de Projeto de Mestrado. Porto: Escola Superior de Educação do IPP.

Nogueira, C. (2012). O sentido do tato, calor e temperatura: Uma abordagem experimental no $2 .{ }^{\circ} \mathrm{CEB}$. Relatório de Projeto de Mestrado. Porto: Escola Superior de Educação do IPP.

Nunes, O. (2012). Trabalho experimental sobre os sons do meio ambiente e as emoções que eles evocam: Estudo de Caso com uma turma do $2^{\circ}$ ano do Ensino Básico. Relatório de Projeto de Mestrado. Porto: Escola Superior de Educação do IPP.

OECD (2010). PISA 2009 Results - What Students Know and Can Do: Student Performance in Reading, Mathematics and Science (Volume I). doi : 10.1787/9789264091450-en.

Reiser, B. J. (2004). Scaffolding Complex Learning: The Mechanisms of Structuring and Problematizing Student Work. Journal of the Learning Sciences, 13 (3), 273-304.

Rogers, Y., Connelly, K. Hazlewood, W., \& Tedesco, L. (2010). Enhancing learning: a study of how mobile devices can facilitate sense making. Personal and Ubiquitous Computing, 14 (2), 111-124.

Quintana, C., Reiser, B. J., Davis, E. A., Krajcik, J., Fretz, E., Duncan, R. G. et al. (2004). A scaffolding design framework for software to support science inquiry. The Journal of the Learning Sciences, $13(3), 337-386$.

Saraiva, E., Lopes, J. Bernardino, Cravino, J. P., Santos, C. A. (2012). How do teachers of physical sciences with different professional experiences use visual representations with epistemic functions in the classroom. Problems of Education in the 21st Century, 42, 97-114.

Silva, M. J., Lopes, J. C., Silva, P. M., Marcelino, M. J. (2010). Sensing the schoolyard: using senses and sensors to assess georeferenced environmental dimensions. In: Proceedings of ACM 1st International Conference and Exhibition on Computing for Geospatial Research \& Application (COM. Geo '10). [Article 40 , 4 pages]. New York: ACM. doi: 10.1145/1823854.1823899.

Shuler, C. (2009). Pockets of Potential: Using Mobile Technologies to Promote Children's Learning. New York: The Joan Ganz Cooney Center at Sesame Workshop.

Teixeira, S. (2012). Uma abordagem experimental à complexidade do conceito de ser vivo com alunos do 2. ${ }^{\circ}$ ano de escolaridade. Relatório de Projeto de Mestrado. Porto: Escola Superior de Educação do IPP.

Van de Pol, J., Volman, M., \& Beishuizen, J. (2010). Scaffolding in Teacher-Student Interaction: A Decade of Research. Educational Psychology Review, 22 (3), 271-296.

Woodyer, T. (2008). The body as research tool: embodied practice and children's geographies. Children's Geographies, 6 (4), 349-362.

Yelland, N., \& Masters, J. (2007). Rethinking scaffolding in the information age. Computers \& Education, 48 (3), 362-382.

Yin, R., (2003). Case Study Research: Design and Methods. Applied Social Research Methods Series, Volume 5. Thousand Oaks: Sage Publications, Inc.

Advised by Clara Viegas, ISEP - School of Engineering, Polytechnic of Porto, Porto, Portugal,

and by José Paulo Cravino, School of Science and Technology,University of Tras-os-Montes e Alto Douro, Vila Real, Portugal, Portugal. 
Maria João SILVA, Joaquim BERNARDINO LOPES, António Alberto SILVA. Using Senses and Sensors in the Environment to Develop Abstract Thinking - a Theoretical and Instrumental Framework

Received: January 31, 2013

Accepted: March 25, 2013

PROBLEMS

OF EDUCATION

IN THE $21^{\text {st }}$ CENTURY

Volume 53, 2013

119

\begin{tabular}{|ll|} 
Maria João Silva & PhD, Professor, in ED - Centre for Research and Innovation in Education \\
& $\begin{array}{l}\text { School of Education of the Polytechnic Institute of Porto, Rua Dr. Roberto } \\
\text { Frias 602, } 4200 \text { Porto, Portugal. } \\
\text { E-mail: mjosilva@ese.ipp.pt } \\
\text { Website: http://mariajoaosilva.pt.to/ }\end{array}$ \\
\hline Joaquim Bernardino Lopes & $\begin{array}{l}\text { Associate Professor, School of Sciences and Technology University of } \\
\text { Trás-os-Montes e Alto Douro; CIDTFF - Research Centre "Didactics and } \\
\text { Technology in Education of Trainers", Apartado 1013, Vila Real, Portugal. } \\
\text { E-mail: blopes@utad.pt }\end{array}$ \\
\hline António Alberto Silva & $\begin{array}{l}\text { PhD, Professor, in ED - Centre for Research and Innovation in Education, } \\
\text { School of Education of the Polytechnic Institute of Porto, Rua Dr. Roberto } \\
\text { Frias 602, 4200 Porto, Portugal. } \\
\text { E-mail: aasilva@ese.ipp.pt }\end{array}$
\end{tabular}

